Portland State University

PDXScholar

$12-2015$

\title{
Data Colonialism through Accumulation by Dispossession: New metaphors for Daily Data
}

Jim Thatcher

University of Washington Tacoma

David O'Sullivan

University of California Berkeley

Dillon Mahmoudi

Portland State University, dillon.mahmoudi@gmail.com

Follow this and additional works at: https://pdxscholar.library.pdx.edu/usp_fac

Part of the Urban Studies Commons, and the Urban Studies and Planning Commons Let us know how access to this document benefits you.

\section{Citation Details}

Thatcher, Jim and O'Sullivan, David and Mahmoudi, Dillon, Data Colonialism Through Accumulation by Dispossession: New Metaphors for Daily Data (December 30, 2015). Environment and Planning D, Forthcoming. Available at SSRN: https://ssrn.com/abstract=2709498

This Post-Print is brought to you for free and open access. It has been accepted for inclusion in Urban Studies and Planning Faculty Publications and Presentations by an authorized administrator of PDXScholar. Please contact us if we can make this document more accessible: pdxscholar@pdx.edu. 


\title{
Title:
}

Data Colonialism through Accumulation by Dispossession: New metaphors for daily data

\author{
Author: \\ Jim Thatcher, University of Washington Tacoma (corresponding author) \\ David O’Sullivan, University of California Berkeley \\ Dillon Mahmoudi, Portland State University
}

\begin{abstract}
:
In recent years, much has been written on 'big data' in both the popular and academic press. After the hubristic declaration of the "end of theory" more nuanced arguments have emerged, suggesting that increasingly pervasive data collection and quantification may have significant implications for the social sciences, even if the social, scientific, political and economic agendas behind big data are less new than they are often portrayed. Compared to the boosterish tone of much of its press, academic critiques of big data have been relatively muted, often focusing on the continued importance of more traditional forms of domain knowledge and expertise. Indeed, many academic responses to big data enthusiastically celebrate the availability of new data sources, and the potential for new insights and perspectives they may enable. Undermining many of these critiques is a lack of attention to the role of technology in society, particularly with respect to the labor process, the continued extension of labor relations into previously private times and places, and the commoditization of more and more aspects of everyday life.
\end{abstract}

In this article, we parse a variety of big data definitions to argue that it is only when individual datums by the million, billion or more, are linked together algorithmically that 'big data' emerges as a commodity. Such decisions do not occur in a vacuum but as part of an asymmetric power relationship in which individuals are dispossessed of the data 
they generate in their day-to-day lives. We argue that the asymmetry of this data capture process is a means of capitalist "accumulation by dispossession" that colonizes and commodifies everyday life in ways previously impossible. Situating the promises of 'big data' within the utopian imaginaries of digital frontierism, we suggest processes of data colonialism are actually unfolding behind these utopic promises. Amidst private corporate and academic excitement over new forms of data analysis and visualization, situating big data as a form of capitalist expropriation and dispossession stresses the urgent need for critical, theoretical understandings of data and society.

\section{Keywords:}

data colonialism, 'big data, ' everyday life, accumulation by dispossession, commodification, critical data studies

\section{Introduction: The Shape of 'big data'}

In recent years, data - be they Big (Lohr, 2014), big (Boellstorff, 2013), 'big' (Dalton and Thatcher, 2014), small (Kitchin and Lauriault, 2014), or raw (Gitelman, 2013) - have moved to center stage in both popular and academic presses. As with other technological developments, such as e-commerce (Leyshon et al., 2005), initial boosterish claims have been followed by more nuanced critiques. In the popular press, critiques have tended to focus on the limitations or failures of 'big data' to produce the promised results (Glanz, 2013; Marcus and Davis, 2014) or on the limitations of both current theory and statistics to interpret data (The Economist, 2014). In academic discussions, while concerns over the utility of big data remain, critiques have emphasized a variety of questions including its role in surveillance (Crampton et al., 2014), its epistemologies (boyd and Crawford, 2012), and its paradigms (Kitchin, 2014). However, even as aspects of 'big data' are pulled apart and questioned in these and other venues, new regimes of data generation, acquisition, and analysis slip into normalcy - as even the most profound technologies 
recede from view as they transform into unquestioned amenities of the everyday (Weiser, 1991; Brown et al., 2011).

This article engages specific asymmetries of the relations between data producers and owners - end-users and app developers - that have become a focal point of value generation in the technology industry. Often self-presented as perpetually "new" (Leszczynski, 2014), the social, scientific, political, and economic agendas behind 'big data' clearly follow longer historical trends such as social physics (Barnes and Wilson, 2014; Wyly, 2014), geodemographic marketing (Dalton and Thatcher, 2015), selfentrepreneurialism (Levenda et al., 2015), and Taylorism (Lohr, 2012), amongst others. These deeper historical understandings of 'big data' open new space for theoretical engagements with data and spatial information. Specifically, we examine 'big data' as a current instantiation of processes of accumulation by dispossession and colonization of the life-world through the commodification and extraction of personal information as data.

Our argument proceeds in three sections: First, building from varied definitions of 'big data,' we focus on the emergence of 'big data' as part of a market-orientation towards continual growth. We argue that it is only when millions and billions of individual pieces of data are linked together algorithmically that the commodity known as 'big data' emerges. Second, decisions concerning what data are meaningful do not occur in a vacuum, rather we argue that the processes by which data are created and exchanged are processes of capitalist accumulation by dispossession. Previously private times and places are commodified and privatized as a new terrain for capital investment and exchange. Further, these processes occur in the context of an asymmetrical power relation between the individuals whose actions generate individual datums and those who come to own and profit from the 'big data' they become. Finally, the asymmetrical extraction of value is shown to presume both quantification and surveillance of the life-world, of lived experience, as a natural, desired outcome of modern life. The teleological nature of this understanding is seen most clearly in the common metaphor of 'big data' - and the 'digital' in general - as new frontiers to be explored, expanded, and conquered (Manyika et al., 2011; Rheingold, 1993). Against this digital frontierism, we suggest the metaphor 
of data colonialism. As one metaphor by which to understand the shifting terrain of data's role in society, data colonialism has the advantage of highlighting the power asymmetries inherent in contemporary forms of data commodification. In so doing, we open new theoretical terrain for engaging with data, furthering an understanding of what is required to study data critically (Batty, 2012).

\section{2. 'Big data,' big growth}

Despite its older historical roots (Barnes and Wilson, 2014; Lohr, 2012), as a term, 'big data' presently sits as a de facto standard through which the world is ordered and understood, a near all-encompassing directive for businesses (McAfee and Brynjolfsson, 2012), science (NSF, 2012), cities (Batty, 2012) and many others. While data have always been big (Farmer and Pozdnoukhov, 2012), at some point the "relentless march" from kilo to tera and beyond (Doctorow, 2008) shifted 'data' from an engineering problem to an epistemological orientation in which more data and better algorithms unveil a greater understanding of the world (boyd and Crawford, 2012). Unremarked and often taken for granted (Wyly, 2014), this epistemological orientation towards the relentless pursuit of 'bigger' data is driven by intense profit-seeking competition within capitalist markets and industries. In this brief section, we develop an understanding of 'big data' attentive not only to existing definitions, but also critical engagements with them; we argue that the epistemological orientation of 'big data' enforces an algorithmic linking of data to create meaning that presumes the quantification of life as capital.

One of the most cited definitions of 'big data,' in both popular and academic presses, traces its roots to a 2001 business intelligence report from Gartner, Inc. (Laney, 2001). The "three V's" of 'big data' - "high-volume (increasing amount of data), high-velocity (speed of data in and out), and/or high-variety (range of data types and sources)" (Horváth, 2012, page 15) - define it explicitly as a technical problem. Although most often embraced and critiqued in terms of its "V's," Sicular (2013), another Gartner employee, has stressed the oft-ignored latter half of Laney's definition as equally important: that 'big data' "demand[s] cost-effective, innovative forms of information processing for enhanced insight and ['big' data-driven] decision making." This definition 
echoes Jacobs (2009) conclusion that the "pathologies of big data are primarily those of analysis"(Jacobs, 2009, page 4).

Both Jacobs and Sicular suggest the shifting, ever-growing nature of 'big data.' What pushed the limits of hardware a decade ago has become a trivial task for most desktop computers today; however, the aim of users of 'big data' is not simply to store and retrieve large datasets for their own sake, but to gain knowledge from them via analysis in order to enhance decision making in the pursuit of efficiencies and profit. The putative 'big' is a moving target that continually pushes beyond the scope of commonly available algorithms and hardware. This has two consequences: First, while there have always been 'big' data sets according to this definition, 'big data' encapsulates an epistemological orientation in which cutting-edge technical feats are performed as a key means of making better decisions in the world. The belief in this myth (boyd and Crawford, 2012) constitutes a certain kind of positivism (Wyly, 2014) which enshrines data as an austere, predictive truth. Second, 'big data' remains a market-oriented epistemology. 'Big data' is "cost-effective," it "enhance[es] insight" in order to generate profit. This marketorientation trumps the use of 'big data' to understand the world as "[t]he capitalist correlation imperative is clear: spurious correlation is fine, so long as it is profitable spurious correlation" (Wyly, 2014, page 681). Regardless of the present profitability of such methods, speculation as to big data's future value, through future data assimilation, new analysis algorithms, or other as yet unknown technologies drives the obsessive need for further 'big data' accumulation. These two conclusions highlight that 'big data' is never merely a scalar function of the limits of computation, rather the pursuit of its growth, the very means by which it is created, mark 'big data' as "profit-laden," akin to how scientific data are "theory-laden" (Kuhn, 1962; Feyerabend, 1957; Hacking, 1983), linked in its very conception as data to a specific market-based epistemology that sees quantification as a for-profit endeavor.

As 'big data' has moved from hyperbolic claims of success to the examination of its actual results, a litany of critiques has emerged (Carr, 2014; Harford, 2014; Kitchin, 2014; Marcus and Davis, 2014; Pearce, 2013; Podesta, 2014). But, 'big data' is not going away; these critiques are not causing its downfall, but, instead, suggest its normalization 
and recession into the banality of the everyday (Dalton and Thatcher, 2014). Perhaps the most powerful critiques demonstrate data's existence as expressions of power (Wilson, 2012) and its ontological entanglement with its own interpretation (Boellstorff, 2013). Taken together these critiques demonstrate not only that 'big data' is never ontologically prior to its interpretation, but also that its very constitution as data is intrinsically bound to social, political, and economic interests. 'Big data,' as a commodity, demands an instrumentalist orientation towards economic growth, one in which claims of objective truth obscure algorithmic processes of selection, analysis, and sorting. For example, spatial sorting algorithms are rarely encountered directly as algorithms, but their existence has come to shape the experience of urban space (Graham, 2010; Kitchin and Dodge, 2011). As algorithms select, link, and analyze ever larger sets of data, they seek to transform previously private, unquantified moments of everyday life into sources of profit. Focusing on the data generated by individuals as they use technology to move through, experience, and come to know the world on a daily basis, we now demonstrate how these data, as part of 'big data' writ large, are commodified and privatized through processes of accumulation by dispossession.

\section{Data Accumulation through Dispossession, Commodifying Everyday Life}

While capitalism's influences upon Internet technologies in general have been the subject of much inquiry (Fuchs, 2008; Žižek, 2004; Graham, 2006; Nakamura, 2008), the specific role of data, their production, and consumption has attracted less interest. Further, the specific role of digital location information and geospatial information as a "fix" for capital (Leszczynski, 2014; Wilson, 2012) and the limits of the knowledge produced (Elwood and Leszczynski, 2013; Thatcher, 2014a) are only now coming into focus. This is despite the explosive growth in the valuation of and investment in both the firms whose main product is such data and in those that consult these data firms. For example, a now-dated 2011 McKinsey Global Institute report estimated that a small segment of such data, personal location information, may yield as much as a $\$ 600$ billion per year surplus (Manyika et al., 2011) while in the same year, Acxiom, a single firm that 
sells personal consumer data, recorded $\$ 1.1$ billion in revenues (Roderick, 2011). Exact valuations of these markets remain difficult as data sellers prefer to operate in secrecy for fear of public reprisal, although a recent report put mobile carrier data sales at approximately $\$ 24$ billion per year (Kaye 2015). More speculatively, recent valuations placed on companies with few assets other than users' personal data and an ability to collect more, have been extraordinarily high. For example, Snapchat, a mobile application for the temporary sharing of images and short videos, is tentatively valued at $\$ 35$ billion by Citigroup, even more than Twitter's market valuation of $\$ 23.5$ billion (see Gelles 2014), while Nest, a company that manufactures data collecting thermostats and other household electronics was acquired by Google for $\$ 3.2$ billion (Oreskovic 2014).

Crampton et al. (2014, page 3) suggests that if the generation of data can be seen as the production of value, then "the object of study would not necessarily be the content of geotagged information (e.g., maps of Tweets and geographies of the internet) but for example how subjects are constituted as laborers in an exploitative economic system" (compare Jhally and Livant 1986, and Andrejevic 2002, who draw on Smythe 1981). In this section, we present the processes by which data is transformed into a commodity that, once produced, can be extracted from the producers to capture surplus-value. We argue that this occurs through asymmetrical relations between data producers (end-users) and data collectors and owners (corporate entities) that mirror processes of primitive accumulation or accumulation by dispossession (Harvey, 2005, 2007) that occur as capitalism colonizes previously non-commodified, private times and places.

"Accumulation by dispossession" refers to the "ongoing" processes that Marx originally termed "primitive" or "original" accumulation (Harvey 2004, 74). In Marx's analysis of capitalism, primitive accumulation had already run its course; capitalism has sprung forth with "the owner of the means of production and subsistence find[ing] the free worker available, on the market, as the seller of his own labour-power" (Marx 1976, 274). The long, complicated process by which the working class is formed (Thompson, 1963) is left outside of the analytical frame of actually-existing capitalism. Harvey, however, argues that accumulation based upon "predation, fraud, and violence" occur in a variety of ways that are haphazard and contingent, but also continual, at their most prominent during 
periods of overaccumulation (Harvey, 2005, page 144). Owners of idle capital seek "to release a set of assets (including labour power) at very low (and in some instances zero) cost. Overaccumulated capital can seize hold of such assets and immediately turn them to profitable use" (Harvey, 2005, page 149).

With regards to 'big data,' these processes privatize data into the hands of technology application creators, obfuscate the quantification and alienation of data from those who create it, and link these data into abstracted bundles of quantified consumers that may be purchased and sold in aggregate. Capital processes transform the very concept of data from a discrete set of observations, often leveraged in Taylorist or Fordist models to increase efficiency, into a multi-dimensional flow of algorithmically linked data points, each emerging within systems of smart device use which increasingly seek to capture and quantify context as well as individual. Daily use of smart devices may have transformed citizens into potential sensors of a host of discrete phenomena (Goodchild, 2008), but it is necessary to ask not only of what citizens have become sensors, but also for whom. As Crampton suggests, this focus opens new terrain for theoretical engagements with data in capitalist modernity, which we take up in the next section.

Previous work has suggested social media platforms commodify the attention time of users, creating infinitely exploitable "prosumers" (Fuchs, 2010, 2011). The packaging and repackaging of the social media 'big data' discussed here into viral maps and charts has been argued to be a key means of focusing and extending attention beyond the individual body, to rewire "both how we know and the significance of that learning process" (boyd and Crawford, 2012; Wilson, 2015, page 2). However, we suggest that the production of 'big data' as a commodity also involves specific processes best understood as accumulation through dispossession (Harvey, 2005, 2007). As users of technology enter into tacit data license agreements with the firms that create and control the technology, they are dispossessed of the right to control those data. Jakobsson and Stiernstedt (2010) have suggested that all Web 2.0 technologies function through the process of accumulation by dispossession, but, here, we illustrate how it specifically functions through commodification and privatization in the generation of 'big data.' 
The commodity form and the processes of commodification have many related, but distinct, definitions throughout social science literature (e.g., Polanyi, 1944; Appadurai, 1996). Building from Polanyi (1944), Prudham (2009) suggests that commodification involves a fundamental shift in production towards the explicit motivation for market exchange (rather than use). This leaves a gap between 'big data' as a commodity and the production of those individual data points which, when linked together, constitute 'big data.' On the one hand, it is trivial to demonstrate that 'big data' exists as a commodity. Its specific market-orientation, the mythologies surrounding it, and the knowledges it produces are all intrinsically linked to the furthering and enhancing of exchange, and to profit (Kitchin, 2014), as we have argued, not only in use but from its inception. On the other hand, it is much less clear how the production of an individual data point by an individual user of technology becomes a commodity distinct and extracted from the individual, overdetermined by algorithms, and exchanged as part of something 'big.'

The very obscurity of transformation from individual data point to commodified, aggregate 'big data' also masks the asymmetrical power relations between users of technology and the almost exclusively corporate entities which algorithmically collect, link, and analyze the data points of many users. Individuals perceive technology and social media use as pleasurable (Thatcher, 2014b), part of a social norm (boyd and Crawford, 2012), or for explicitly exchange based reasons (Lindqvist et al., 2011) The individual datum produced from a single user at a given time and place (e.g., posting a picture of a meal to Instagram) is both nearly meaningless (Wilson, 2015) and valueless (Stalder, 2014) until it is linked to the user's past data produced, the user's network of other users, the user's growing network of location data, and the temporal rhythms and spatial patterns embedded in data from many users. Conversion from an individual datum to an aggregated, digital commodity necessitates linking data across users, spaces, and times. These amalgamated data become necessarily large ('big') and thus a site for algorithmic selection, interpretation, and analysis as to what data to include and exclude. Further, the very limits of what can ever be known through this process are governed by algorithms, which are themselves developed by profit-seeking firms. Firms 'mine' these data for profit-seeking purposes (Arvidsson and Colleoni, 2012; Fernback, 2007); Kitchin (2014, page 144) identifies four main purposes: identifying individuals and behaviors, 
improving customer-segment targeting precision, improving personalized advertisement relevance, and developing forecasting capabilities. In order to create these linked, necessarily 'big' sets of data to mine, firms must assert the rights to the data generated by millions of users of everyday technologies. Previously private experiences - such as the location of meals (Foursquare, Yelp) or arranging romantic encounters (Tindr, Grindr, OkCupid) - are quantified and become data points within privately owned systems.

Privatization is the process by which legal title to an object is granted to individuals or institutions allowing them to dispose of said object as they desire (Castree, 2003, page 279). Privatization, the creation of private property, is not a unique feature to capitalist commodification; however, it is a precondition for all capitalist commodification. Private property in capitalism requires the "annihilation of that private property which rests on the labour of the individual himself" and is a fundamental feature of capitalism (Marx, 1976, 940). While the specific means and object of commodification may differ, "accumulation by dispossession" fundamentally entails the making private of something previously not. Recent scholarship has demonstrated a host of new mechanisms for privatization such as intellectual property rights over populations' genetic materials (Harvey, 2007). The corporate privatization of previously private (to the individuals) moments occurs through the processes of 'big data's' generation and reflects part of late capitalism's “corporeal corkscrewing inwards" (Beller, 2012, page 8). Similarly, while the specific means of privatization may differ for different types of 'big data,' for the types discussed here it occurs primarily through End-User-License-Agreements (EULAs).

$E U L A$ s take many forms, often as pop up windows that appear when an application is installed or used for the first time. Although research has shown these agreements are rarely read (Lin et al., 2012), application creators regularly claim ownership over wide swathes of data not readily apparent to end-users (Bigge, 2006). This process of privatization and control of access to individuals' own data is common across Internet industries (Gehl, 2010) and forms a critical moment in the commodification of individual data into 'big data.' Previously public - or, in this case, non-quantified - information about daily life is quantified and privatized, not in the hands of those who generated it, 
but of those who created the application; whether the espoused motivations for quantification are to enhance the service offered or add value to the data set being assembled, the transfer of ownership remains.

Alienation and privatization are intrinsically related processes, with the former referring to the "capacity of a given commodity ... to be physically and morally separated from their sellers" (Castree, 2003, page 279). The alienation produced through technology and technical rationality has been a core theme in critical theory and social science research on technology's function in modernity (c.f. Adorno and Horkheimer, 2007; Feenberg, 1991, 1991; Marcuse, 1964; Marx, 1987) and 'big data' functions as a techno-social achievement that obscures the very processes of alienation it engenders. While the EULA remains the principal legal means by which developers and firms claim ownership of data, the actual exchange of it from the generator to the collector, from the user to the firm, is obscured through the promise and necessity of technology use in everyday life. 


\section{nnl. voda AU ₹ 11:16 PM 1 \% $100 \% \leftleftarrows$}

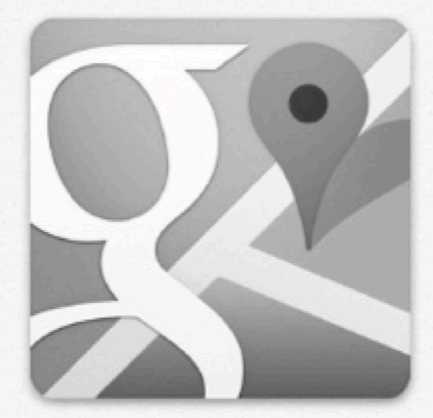

\section{Welcome to Google Maps}

\section{By using this application, you agree to the Terms of Service and Privacy Policy.}

Help us improve Google, including traffic and other services. Anonymous location data will be collected by Google's location service and sent to Google, and may be stored on your device. Learn more

\section{Accept \& continue}

fig 1. Agreeing to Google's Terms of Service and Privacy Policy is required to use Google Maps (image source: http://www.quora.com/Where-are-Apple-EULA-for-appGoogle-maps-available) 
Central to the obfuscation of the relationship between user and firm is that users are seen to voluntarily and willingly adopt technologies, and agree to any associated EULAs, as part of broad social norms and/or as part of an individual embodiment of the enterprise form (Foucault, 1997, 2008). As Lanier puts it "The reason people click 'yes' is not that they understand what they're doing, but that that it is the only viable option other than boycotting a company in general, which is getting harder to do" (Lanier, 2014, 314). While the data generator uses the technology to perform social activities and or selfentrepreneurial activities, the firm, in exchange, extracts value through the quantification of the data. The data generator, as producer of value, is denied access to the commodity form of value produced through its privatization as property and alienation into the control of the firm. As a process of commodification, the data producer is on the one hand alienated and excluded from the final data commodity, and on the other the firm decontextualizes, through a process of quantification, the activity which it observed (Feenberg, 2008). The alienation, exclusion and decontextualization processes are necessary to make the data legible to other market-oriented rational systems that will consume the aggregated data.

On one level, the abstraction of 'big data' seems obvious: sensors quantify data into homogenized formats, selecting - before collection - what will and will not be included in a given dataset. This is an inherent part of application and database design and a fundamental aspect of computer programming (Kitchin and Dodge, 2011, Schuurman 2008), which requires that phenomena and events in the world be encoded in textual, numeric or other reductionist forms (Ullman, 1997; Lanier, 2010). On the other, a more subtle process occurs as data are linked together and exchanged. To the data vendor, the purpose of this type of 'big data' is to transform unpredictable individual consumers into predictable statistical aggregates of consumption (Ascher 2016). This is the "insight" offered by data generated through everyday technology, the transformation from a specific individual in the lifeworld to a percentage chance to purchase any given commodity; to data vendors, the individuals that constitute 'big data' matter far less than their algorithmically-sorted, aggregate identities. Each data point from an application is abstracted and valued at a specific level but, when linked together, those data points are transformed into buckets of consumers, abstracted aggregate individuals whose 
consumption patterns are predictable in ways that have value - for example, although prices fluctuate, it was possible to purchase 1,000 followers for \$5 in 2013 (Perlroth, 2013) .

Using sets of quantified markers to predict behavior of an individual within a market is hardly a new idea, for example, credit scores have long been used to determine loan rates and risk pools to determine insurance rates; and the "underlying drive to control through quantification" has long been an underlying theme of ubiquitous computing (Dourish and Mainwaring, 2012, 5). However, 'big data' both promises and signifies something more. Developing out of, and often involving the same vendors as geodemographics, the myth of 'big data' adds the promise of ever-greater segmentation and targeting in order to shape and control consumptions patterns with ever more precise targeting - an epistemic break that leaps from the area to the individual (Dalton and Thatcher, 2015; see also Goss, 1995). Where Michael Curry (1998) presciently demonstrated the emergence of the "digital individual," "big data' signals the transformation of the data collection apparatus into Greenfield's (2006) “everyware" and the loss of even the pretext of an individual's ability to control said identity. As this occurs, to capitalist interests, the linked data about the individual comes to stand for the individual who created it. This is the individual that capital can see through 'big data' (Robertson 2004): an individual dispossessed and alienated from the very data they generate, one who has been reduced to a set of data points created through technology use that place users within abstracted, aggregate identities. Linked together, billions of data points promise an ever smoother, more predictable surface of capitalist consumption. As such, 'big data' serves as a 'fix' for capitalism's inherent tendencies towards overaccumulation, not through a spatial expansion outwards, but by a rendering smooth of the rough surfaces of individuals' lives as they become knowable as commodified representations of self.

This transformation of everyday objects and practices into sensors that first quantify and then dispossess individuals of their self-generated data signifies a new regime of relation between capital and the individual. 'Big data' produces the commodified, quantified self (Wilson, 2014) not only in how it encourages individuals to make use of technology, but also in its creation of representations of individuals as 
commodities. Social norms, aesthetic pleasures, and perceived values encourage the use of an increasing array of technologies equipped with sensors that quantify and then communicate data about previously private times and places to thirdparty actors. Dispossessed of any control of their data, individuals and their individual data points become analyzed and linked together as commodities, their value deriving from the promised ability to produce continual, predictable streams of sales; the quantified, commodified individual able to be called forth through algorithmic analysis within a smooth surface of consumption. Many metaphors have been used to describe the new relations between individual, data, and society - from digital frontierism (Rheingold, 1993) to "playbour" (Kane, 2004) - in the concluding section of this article, we argue a more apt metaphor to be "data colonialism." We conclude with a discussion of how its use opens new terrain for sustained theoretical engagements with data as data from a variety of perspectives.

\section{Against the frontier - Data Colonialism}

Four years ago, 'big data' was already the "next frontier for innovation, competition and productivity" (Manyika et al., 2011). This type of speculative imaginary is neither new nor unique with regards to digital information technologies. The Internet, in all of its various forms - from bulletin board systems to mobile device - has long been described as a "frontier." In its more lurid and utopic forms, the digital frontier is described as a "freewheeling space crafted by wily pioneers and ingenious scientists which is being populated by those who wish to participate in the space's inherent freedom" (Shuler, 2005). With clear antecedents in Manifest Destiny and the Turner thesis (Turner, 1921), early evangelists of internet technologies, like Howard Rheingold, explicitly make use of a pioneer mythos in which the Internet becomes an open space of unlimited freedom (Hirschorn, 2010), which also has ties to the 1960s counterculture and experiments in communal living that followed (Turner 2008). Much like the Turner thesis itself (Cronon, 1991; Limerick, 1987; Mondi, 2006; etc.), the application of these metaphors to digital information technologies has been critiqued from a number of standpoints, for example, Galloway's work on the functional and disciplining role that protocols play 2006), 
Kitchin and Dodge's work on the role software plays in the ordering and production of space (2011), or Thrift and French's work on the automatic production of space (2002); however, in this final section, we explore the role "colonization" has and continues to play as a metaphor for 'big data.' Beginning with its use in relation to the utopic digital frontier, we demonstrate the central theoretical role it can play vis-à-vis the commodification of data and its accumulation through dispossession.

Rheingold (1993, page 10) claims that his "virtual communities also inhabit [his] life." He has been "colonized" (ibid.). In this rendering, colonization is a distinctly positive process, the freedoms of digital technologies have recursively inscribed themselves in and altered his very sense of self. In this rendering, colonization remains a positive metaphor so long as the digital frontier remains 'free':

"[B]ig money and big power always found ways to control our communications media when they emerged in the past. [...] What we know and do now is important because it is still possible for people $[\ldots]$ to make sure this new sphere of vital human discourse remains open $[\ldots]$ before the political and economic big boys seize it, censor it, meter it, and sell it back to us." (Rheingold, 1993, page 5)

Such influences would be able to inherently shape and therefore control the experiences offered through digital technologies. While perfect and 'open' information offers the potential realization of “[Adam] Smith's ideal” market (Gates, 1995, page 180), 'big power and big money' represent the fictitious antithetical.

The closing off of digital technologies, and of the Internet specifically, has been discussed in the popular press since at least 2003 (Totty, 2003), but such critiques, still present in the popular press over a decade later, rest on an essentially positive, optimistic assumption of the comingling of data, technology, and body. The rhetoric surrounding Net Neutrality, for example, hinges upon distinctions between the "open" and "closed" internets (Kehl and Morris, 2014). In that discourse, telecom corporations play the role of the "big power and big money" from which the internet must be defended, with the "open" Internet as an internet better for individuals as consumers and users of technology in their daily lives (Kang, 2014). Regardless of the merits - and distinct limitations - of 
Rheingold's vision, the current era of 'big data' presents a much starker reality. Whereas sensors and communication technologies have "colonized" the lifeworld, they have done so as a means of extracting value by dispossessing individuals of their data. In exchange for this quantification of the everyday, individuals are offered notional advantages pleasurable experiences in which aspects of their lives are algorithmically sorted and produced for them based on their quantified markers, for example, the offering of nearby restaurants and bars based on previous inputs (Foursquare) or the suggesting of nearby potential sexual partners (Grindr, Tindr). Perhaps less obviously, this occurs through the continual 'filtering' of news, personal information feeds, and search results presented on services such as Facebook, Amazon, and Google via algorithms that sort and select based on the data linked together to form their digital identities (Pariser, 2011). 'Big data,' as part of its mythology, promises an idealized market, but it is one of predictable, modeled consumption. The asymmetry of the value of 'big data', emerging only in aggregate, ensures that only "big money and big power" are able to reap its purported benefits (Golumbia, 2009). 'Big data' is a colonial policy, but it is one in which, rather than opening the idealized markets of digital frontierism's problematic imaginary, we have become subject to them. Sensors quantify, alienate, and extract conceptions of self, reducing life as seen by capital to what can be recorded and exchanged as digital data. Linked together in aggregate, the sum total of data produced by an individual marks them into an abstracted bucket, a digital commodity that may be continually bought and sold in order to call forth an orderly, predictable stream of consumption.

Two critical conclusions can be drawn from these processes: First, accumulation by dispossession is an intrinsic process to capital that continues to occur in novel ways alongside other capital processes (Harvey, 2005). In 'big data' it continues its role as a key means by which capitalism staves off its inherent tendencies toward over-production. Second, it does so by corkscrewing into the body as well as the mind (Beller, 2012; Stiegler, 2010). Rather than traditional expansionary tactics, the colonization of the lifeworld functions in the same way, but occurs through the panoply of sensors, devices, and EULAs through which individuals navigate late capitalist modernity. 
These conclusions stand Rheingold and his metaphorical imaginary on their head and open a new space for sustained theoretical engagement with 'big data.' If the processes by which 'big data' comingle with everyday life are understood not as a 'frontier' to be colonized, but as processes by which everyday life is colonized by 'big money and big power,' then a new theoretical terrain for understanding 'big data' is opened. Whereas uncovering the obfuscated historical antecedents of 'big data' allows critiques to be drawn from the past forward (Barnes and Wilson, 2014; Dalton and Thatcher, 2015), understanding the processes of 'big data' as those of accumulation by dispossession and colonization of everyday life furthers this engagement. 'Big data' is once again not something new, but part of the continuous, entangled processes by which technologies operate under capitalism (Dyer-Witheford, 1999). Further, the specific definition of 'big data' as overdetermined by algorithms developed under profit-imperatives highlights the recursive means by which such data attempt to colonize and therefore control everyday life. The upwards of 1,500 data points per person that firms link together and sell (Singer, 2012) are "profit-laden," designed and developed to dispossess end-users of data generated in their everyday life.

To understand and critically engage with data's increasing role in the everyday, it is necessary to remember the impetuses and epistemologies that shape its construction. This article argues a small piece of a much larger process, demonstrating how the data created through daily smart device use is commodified through processes of accumulation by dispossession and how, in turn, this occurs through the ongoing colonization of life by capital (Crary, 2014). It is a small part of what must become a larger project: the political economy of geospatial data. Necessary in such a project would be a more full tracing of the dynamics that shape technology firms, exploring the unequal distribution of wealth between venture capitalist, corporate owner, and IT sector worker, as well as the need to focus on the spatial variations of the colonization of life through data. We write from a Western perspective, one focused on the practices and economies of Silicon Valley and its imitators; however, as the recent death of a woman using Waze to navigate Brazil attests (Darlington, 2015), the development of data regimes is distinctly uneven. Finally, the 'big data' we have discussed is necessarily limited to that information which is 
(speculatively) believed to be able to produce profit. This data is limited to what 'big data' can quantify, but it has become the life that capital can see. 


\section{REFERENCES}

Horkheimer, M., and T. W. Adorno. 2001. Dialectic of Enlightenment. New York: Continuum.

Andrejevic M, 2002, “The Work of Being Watched: Interactive Media and the Exploitation of Self-Disclosure" Critical Studies in Media Communication 19(2) $230-248$

Arvidsson, A and Colleoni, E, 2012, "Value in Informational Capitalism and on the Internet" The Information Society 28(3) 135-150.

Barnes, T J and Wilson, M W, 2014a, "Big Data, social physics, and spatial analysis: The early years" Big Data \& Society 1(1) 1-14.

Batty, M, 2012, "Smart cities, big data" Environment and Planning B: Planning and Design 39(2) 191.

Beller, J, 2012, "Wagers Within the Image: Rise of Visuality, Transformation of Labour, Aesthetic Regimes" Culture Machine 13, http://www.culturemachine.net/index.php/cm/article/viewDownloadInterstitial/46 $6 / 485$.

Bigge, R, 2006, "The cost of (anti-) social networks: Identity, agency and neo-luddites" First Monday 11(12), http://firstmonday.org/ojs/index.php/fm/article/view/1421.

Boellstorff, T, 2013, "Making big data, in theory" First Monday 18(10), http://firstmonday.org/ojs/index.php/fm/article/view/4869.

boyd, danah and Crawford, K, 2012, "Critical Questions for Big Data: Provocations for a Cultural, Technological, and Scholarly Phenomenon" Information, Communication \& Society 15(5) 662-679.

Brown, B, Chui, M, and Manyika, J, 2011, “Are you ready for the era of 'big data'?” McKinsey Quarterly (4) 24-35.

Carr, A, 2014, “The Next Stage in the Big Data Phenomenon?" The Huffington Post UK, http://www.huffingtonpost.co.uk/andrew-carr/the-next-stage-in-thebig_b_5860010.html.

Castree, N, 2003, “Commodifying what nature?” Progress in Human Geography 27(3) 273-297.

Crampton, J W, Roberts, S M, and Poorthuis, A, 2014, “The New Political Economy of Geographical Intelligence" Annals of the Association of American Geographers 104(1) 196-214.

Crary, J. 2014. 24/7: late capitalism and the ends of sleep. London: Verso.

Cronon W, 1992 Nature's Metropolis: Chicago and the Great West Reprint edition (W. W. Norton \& Company, New York).

Curry, M, 1998 Digital Places: Living with Geographic Information Technologies (Routledge, London). 
Dalton, C, and Thatcher, J 2015, "Inflated granularity: Spatial "Big Data" and geodemographics" Big Data \& Society July-December 2015: 1-15.

Dalton, C, and thatcher, J 2014, "What does a critical data studies look like and why do we care?" Society and Space Open Site, May 20 2014, $\mathrm{http}$ //societyandspace.com/material/commentaries/craig-dalton-and-jim-thatcherwhat-does-a-critical-data-studies-look-like-and-why-do-we-care-seven-points-fora-critical-approach-to-big-data/

Darlington, S, 2015, "Waze app directions take woman to wrong Brazil address, where she is killed" $C N N$, http://www.cnn.com/2015/10/05/americas/brazil-wrongdirections-death/

Doctorow, C, 2008 Content: Selected Essays on Technology, Creativity, Copyright, and the Future of the Future (Tachyon Publications San Francisco), http://www.jus.uio.no/sisu/content.cory_doctorow/portrait.a5.pdf.

Dourish, P, and Mainwaring, S D, 2012 "Ubicomp's Colonial Impulse" UbiComp '12 Proceedings of the 2012 ACM Conference on Ubiquitous Computing, pages 133$142 \mathrm{http}: / / w w w . d o u r i s h . c o m / p u b l i c a t i o n s / 2012 /$ ubicomp2012-colonial.pdf

Dyer-Witheford N, 1999 Cyber-Marx: Cycles and Circuits of Struggle in High Technology Capitalism (Urbana IL, University of Illinois Press)

Elwood, S and Leszczynski, A, 2013, "New spatial media, new knowledge politics" Transactions of the Institute of British Geographers 38(4) 544-559.

Farmer, C J and Pozdnoukhov, A, 2012, "Building streaming GIScience from context, theory, and intelligence", in Proceedings of the Workshop on GIScience in the Big Data Age. Columbus, Ohio, http://stko.geog.ucsb.edu/gibda2012/GIBDAProceedings.pdf

Feenberg, A, 1991 Critical Theory of Technology (Oxford, Oxford University Press)

Feenberg, A, 2008, "From Critical Theory of Technology to the Rational Critique of Rationality" Social Epistemology 22(1) 5-28.

Fernback, J, 2007, "Selling ourselves? Profitable surveillance and online communities" Critical Discourse Studies 4(3) 311-330.

Feyerabend P, 1993 Against Method (London, Verso).

Foucault, M, 1997 Ethics: Subjectivity and Truth 1st edition Ed P Rabinow (New York, The New Press).

Foucault, M, 2008 The Birth Of Biopolitics: Lectures At The College De France, 19781979 (Lectures At The College De France) (New York, Palgrave Macmillan).

Fuchs, C, 2008 Internet and Society: Social Theory in the Information Age (New York, Routledge).

Fuchs, C, 2010, "Labor in Informational Capitalism and on the Internet" The Information Society 26(3) 179-196.

Fuchs, C, 2011, "Web 2.0, Prosumption, and Surveillance” Surveillance \& Society 8(3) 288-309. 
Gates, B 1995 The Road Ahead (Penguin Books).

Gehl, R W, 2010 A Cultural and Political Economy of Web 2.0, PhD Dissertation, George Mason University, http://digilib.gmu.edu/xmlui/handle/1920/5886.

Gelles D, 2014, “Citigroup Says Instagram Is Worth \$35 Billion” DealBook, http://dealbook.nytimes.com/2014/12/19/citigroup-says-instagram-is-worth-35billion/

Gitelman L ed, 2013 “Raw Data” Is an Oxymoron (Cambridge MA, The MIT Press).

Glanz, J, 2013, “Is Big Data an Economic Big Dud?” The New York Times, http://www.nytimes.com/2013/08/18/sunday-review/is-big-data-an-economic-bigdud.html.

Golumbia, D. 2009. The Cultural Logic of Computation. Cambridge, MA: Harvard University Press.

Goodchild, M F, 2007, "Citizens as sensors: the world of volunteered geography" GeoJournal 69(4) 211-221.

Goodchild, M F and Glennon, J A, 2010, “Crowdsourcing geographic information for disaster response: a research frontier" International Journal of Digital Earth 3(3) 231-241.

Goss, J, 1995, “We Know Who You Are and We Know Where You Live': The Instrumental Rationality of Geodemographic Systems” Economic Geography 71(2) 171-198.

Graham, M, 2010, "Neogeography and the palimpsests of place: Web 2.0 and the construction of a virtual earth" Tijdschrift voor Economische en Sociale Geografie 101(4) 422-436.

Greenfield A, 2006, Everyware: The Dawning Age of Ubiquitous Computing (New Riders Publishing, Berkeley, CA).

Hacking I, 1983 Representing and Intervening: Introductory Topics in the Philosophy of Natural Science (Cambridge University Press, Cambridge).

Harford, T, 2014, "Big data: are we making a big mistake?" Financial Times, http://www.ft.com/cms/s/2/21a6e7d8-b479-11e3-a09a00144 feabdc0.html\#axzz2ysdIXgD2.

Harvey D, 2007, "Neoliberalism as Creative Destruction" The Annals of the American Academy of Political and Social Science 610(1) 22-44

Harvey, D, 2007 The Limits to Capital Updated (Verso).

Harvey, D, 2005 The New Imperialism (Oxford University Press).

Harvey F, 2013, “To Volunteer or to Contribute Locational Information? Towards Truth in Labeling for Crowdsourced Geographic Information", in Crowdsourcing Geographic Knowledge Eds D Sui, S Elwood, and M Goodchild (Springer Netherlands). 
Hecht, B J and Gergle, D, 2010, "On the localness of user-generated content", in Proceedings of the 2010 ACM Conference on Computer supported cooperative work (ACM), pp 229-232, http://dl.acm.org/citation.cfm?id=1718962.

Hirschorn, M, 2010, "Closing the digital frontier" The Atlantic, http://longnow.org/static/djlongnow_media/press/pdf/020100708-HirschornClosing_the_Digital_Frontier.PDF.

Horváth, I, 2012, "Beyond advanced mechatronics: new design challenges of SocialCyber-Physical systems", in Proceedings of the ACCM-Workshop on "Mechatronic Design" (Linz, Austria).

Jacobs, A, 2009, “The pathologies of big data" Communications of the ACM 52(8) 3644.

Jakobsson, P and Stiernstedt, F, 2010, "Pirates of Silicon Valley: State of exception and dispossession in Web 2.0" First Monday 15(7). http://firstmonday.org/ojs/index.php/fm/article/view/2799

Jhally S, Livant B, 1986, "Watching as Working: The Valorization of Audience Consciousness" Journal of Communication 36(3) 124-143

Johnson, P A, Sieber, R E, Magnien, N, and Ariwi, J, 2012, “Automated web harvesting to collect and analyse user-generated content for tourism" Current Issues in Tourism 15(3) 293-299.

Kane P, 2005 The Play Ethic: A Manifesto for a Different Way of Living (London, Pan Macmillan)

Kang C, 2014, "The effect of net neutrality rules on consumers" The Washington Post, http://www.washingtonpost.com/business/technology/the-effect-of-net-neutralityrules-on-consumers/2014/04/24/59c90556-cbda-11e3-95f77ecdde72d2ea_story.html

Kaye, K 2015, "The \$24 Billion Data Business That Telcos Don't Want to Talk About" Advertising Age, http://adage.com/article/datadriven-marketing/24-billion-databusiness-telcos-discuss/301058/

Kehl D, Morris S, 2014, “The 2014 Open Internet Roller Coaster” Slate, http://www.slate.com/articles/technology/future_tense/2014/12/net_neutrality_de bate_2014_the_open_internet_rules_roller_coaster.html

Kitchin, R, 2014 The Data Revolution: Big Data, Open Data, Data Infrastructures and their Consequences (London, Sage).

Kitchin R, Lauriault T P, 2014, “Small Data, Data Infrastructures and Big Data”, Social Science Research Network, Rochester, NY, http://papers.ssrn.com/abstract $=2376148$

Kitchin, R and Dodge, M, 2011 Code/Space: Software and Everyday Life (Cambridge MA, MIT Press).

Kuhn T S, 1962 The Structure of Scientific Revolutions (Chicago IL, University of Chicago Press). 
Laney, D, 2001, “3D Data Management: Controlling Data Velocity, Volume, Variety.”, META Group Research Note. http://blogs.gartner.com/douglaney/files/2012/01/ad949-3D-Data-Management-Controlling-Data-VolumeVelocity-and-Variety.pdf

Lanier J, 2010, You Are Not a Gadget: A Manifesto (New York: Knopf)

Leszczynski, A, 2014, "On the neo in neogeography" Annals of the Association of American Geographers 104(1) 60-79.

Levenda A M, Mahmoudi D, Sussman G, 2015, "The Neoliberal Politics of 'Smart': Electricity Consumption, Household Monitoring, and the Enterprise Form”, Canadian Journal of Communication 40(2).

Lindqvist J, Cranshaw J, Wiese J, Hong J, Zimmerman J, 2011, “I'm the mayor of my house: examining why people use foursquare-a social-driven location sharing application", in Proceedings of the SIGCHI Conference on Human Factors in Computing Systems (ACM), pp 2409-2418, http://dl.acm.org/citation.cfm?id=1979295

Leyshon, A, French, S, Thrift, N, Crewe, L, and Webb, P, 2005, “Accounting for ecommerce: abstractions, virtualism and the cultural circuit of capital" Economy and Society 34(3) 428-450.

Lin, J, Amini, S, Hong, J I, Sadeh, N, Lindqvist, J, and Zhang, J, 2012, "Expectation and purpose: understanding users' mental models of mobile app privacy through crowdsourcing", in Proceedings of the 2012 ACM Conference on Ubiquitous Computing (ACM), pp 501-510, http://dl.acm.org.proxy.lib.pdx.edu/citation.cfm?id=2370290.

Lohr, S, 2012, "Sure, Big Data Is Great. But So Is Intuition.” The New York Times, http://www.nytimes.com/2012/12/30/technology/big-data-is-great-but-dontforget-intuition.html.

Manyika, J, Chui, M, Brown, B, Bughin, J, Dobbs, R, Roxburgh, C, and Byers, A H, 2011, "Big data: The next frontier for innovation, competition, and productivity" (The McKinsey Global Institute), http://www.mckinsey.com/insights/business_technology/big_data_the_next_fronti er_for_innovation.

Marcuse, H, 1964 One-Dimensional Man: Studies in the Ideology of Advanced Industrial Society (Boston MA, Beacon Press).

Marcus, G and Davis, E, 2014, "Eight (No, Nine!) Problems With Big Data" The New York Times, http://www.nytimes.com/2014/04/07/opinion/eight-no-nineproblems-with-big-data.html.

Marx K, 1976 Capital, Volume 1 (London, Penguin).

Marx, L, 1987, “Does Improved Technology Mean Progress” Technology Review 90(1) 33-41.

McAfee, A and Brynjolfsson, E, 2012, "Big Data: The Management Revolution." Harvard Business Review 90(10) 60-68. 
Miller, C C, 2006, "A beast in the field: The Google Maps mashup as GIS/2" Cartographica: The International Journal for Geographic Information and Geovisualization 41(3) 187-199.

National Science Foundation, "NSF Announces Interagency Progress on Administration's Big Data Initiative - Press Release 12-187” National Science Foundation (NSF) News, http://www.nsf.gov/news/news_summ.jsp?cntn_id=125610

Oreskovic A, 2014, "Google to acquire Nest for $\$ 3.2$ billion in cash” Reuters, http://www.reuters.com/article/2014/01/13/us-google-nestidUSBREA0C1HP20140113

Palen, L, Vieweg, S, Liu, S B, and Hughes, A L, 2009, "Crisis in a networked world features of computer-mediated communication in the April 16, 2007, Virginia Tech event" Social Science Computer Review 27(4) 467-480.

Pariser E, 2012 The Filter Bubble: How the New Personalized Web Is Changing What We Read and How We Think Reprint edition (Penguin Books, New York)

Pearce, R, 2013, "Big data is BS: Obama campaign CTO” CIO, http://www.cio.com.au/article/462961/big_data_bs_obama_campaign_cto/.

Perlroth, N, 2013, "Fake Twitter Followers Become Multimillion-Dollar Business" New York Times: Bits http://bits.blogs.nytimes.com/2013/04/05/fake-twitter-followersbecomes-multimillion-dollarbusiness/?nl=todaysheadlines\&emc $=$ edit_th_20130406\&_r $=0$

Podesta, J, 2014, "Big Data: Values and governance", in Remarks Delivered by Counselor John Podesta, at The White House Office of Science Technology and Policy (UC Berkeley School of Information, Berkeley, CA) http:/www.ischool.berkeley.edu/newsandevents/events/2014bigdataworkshop.

Polanyi, K, 1944 The Great Transformation: The Political and Economic Origins of Our Time (Boston MA, Beacon Press).

Presley, S, 2011 Mapping out \#LondonRiots. NFPvoice. http://nfpvoice.com/?p=1348

Prudham, S, 2009, Commodification, pages 123-142 in A Companion to Environmental Geography eds N. Castree, D. Demeritt, D. Liverman and B. Rhoads (WileyBlackwell, Oxford, UK)

Rheingold, H. 1993. The Virtual Community: Homesteading on the Electronic Frontier. (Reading MA, Addison-Wesley).

Schneier, B, 2014, "NSA robots are 'collecting' your data, too, and they're getting away with it" The Guardian, http://www.theguardian.com/commentisfree/2014/feb/27/nsa-robots-algorithmsurveillance-bruce-schneier.

Schuurman, N, 2009, "The new Brave New World: geography, GIS, and the emergence of ubiquitous mapping and data" Environment and Planning. D: Society and Space 27(4) 571-580. 
Schuurman, N. 2006. Formalization Matters: Critical GIS and Ontology Research. Annals of the Association of American Geographers 96 (4):726-739.

Shuler, J, 2005, "Ever onward: the frontier myth and the information age" Fast Capitalism 1(1), http://www.uta.edu/huma/agger/fastcapitalism/1_1/shuler.html.

Sicular, S, 2013, “Gartner's Big Data Definition Consists of Three Parts, Not to Be Confused with Three 'V's" Forbes, http://www.forbes.com/sites/gartnergroup/2013/03/27/gartners-big-datadefinition-consists-of-three-parts-not-to-be-confused-with-three-vs/.

Smythe D W, 1981 Dependency Road: Communications, Capitalism, Consciousness, and Canada (Praeger, Norwood, N.J)

Stiegler, B 2010 For a New Critique of Political Economy (Polity, Cambridge, MA).

Thatcher, J, 2014a, "Living on fumes: Digital footprints, data fumes, and the limits of spatial big data" International Journal of Communication 8: 1765-1783.

Thatcher, J, 2014b, "Code and the mediation of space: The pleasures of being placed" Paper presented at the Association of American Geographers Annual meeting, Tampa, FL. http://meridian.aag.org/callforpapers/program/AbstractDetail.cfm?AbstractID $=58$ 356

The Economist, 2014, "The backlash against big data" The Economist, http://www.economist.com/blogs/economist-explains/2014/04/economistexplains-10.

Thompson, E P, 1963 The Making of the English Working Class (New York, Vintage Books).

Thrift, N., and S. French. 2002. The automatic production of space. Transactions of the Institute of British Geographers 27 (3):309-335.

Turner, F J, 1921 The Frontier in American History (New York, Henry Holt and Company). Available at http://www.gutenberg.org/files/22994/22994-h/22994h.htm

Turner, F. 2008. From Counterculture to Cyberculture: Stewart Brand, the Whole Earth Network, and the Rise of Digital Utopianism. Chicago: University Of Chicago Press.

Weiser M, 1991, "The computer for the 21st century" Scientific American 265(3) 94104.

Wilson, M W, 2012, "Location-based services, conspicuous mobility, and the locationaware future" Geoforum 43(6) 1266-1275. 
Wilson, M W, 2015, "Morgan Freeman is dead and other big data stories" Cultural Geographies 22(2) 345-349.

Wilson M W, 2014, "Quantified Self-City-Nation at The Programmable City Launch Event, Ireland”, http://gis.harvard.edu/publications/quantified-self-city-nationprogrammable-city-launch-event-ireland

Wyly, E, 2014, “Automated (post) positivism” Urban Geography 35(5) 669-690.

Žižek, S, 2004, “The ongoing ‘soft revolution”" Critical Inquiry 30(2) 292-323. 